\title{
GAMBARAN PEMANFAATAN PELAYANAN KESEHATAN TRADISIONAL PADA PENDUDUK LANJUT USIA DI INDONESIA (BERDASARKAN DATA RISKESDAS 2018)
}

\section{Utilization of Traditional Health Services for Elderly In Indonesia (Based on 2018 Riskesdas Data)}

\author{
Rukmini dan Lusi Kristiani \\ UPF Inovasi Teknologi Kesehatan, Puslitbang Humaniora dan Manajemen Kesehatan \\ Naskah masuk: 18 September 2020 Perbaikan: 7 Januari 2021 Layak terbit: 1 Februari 2021 \\ https://doi.org/10.22435/hsr.v24i1.3843
}

\begin{abstract}
ABSTRAK
Salah satu upaya kesehatan yang berpeluang meningkatkan status kesehatan lansia adalah pelayanan kesehatan tradisional (Yankestrad). Tulisan ini bertujuan untuk mengetahui gambaran pemanfaatan Yankestrad pada penduduk lansia di Indonesia. Sumber data dalam analisis ini adalah Riskesdas 2018. Riset yang dilakukan oleh Kementerian Kesehatan dengan unit analisis lansia ( $\geq 60$ tahun). Analisis data secara deskriptif. Hasil menunjukkan, pemanfaatan Yankestrad pada lansia $37,0 \%$ dan upaya sendiri dengan obat tradisional 17,3\%. Lansia muda terbanyak memanfaatkan Yankestrad $(37,9 \%)$, sedangkan upaya sendiri dengan obat tradisonal didominasi lansia perempuan (18,3\%) di perdesaan (19,5\%). Pemanfaatan Toga pada lansia di Indonesia $(31,9 \%)$, terbanyak perempuan $(33,3 \%)$ di perdesaan $(36,3 \%)$. Jenis Yankestrad terbanyak dimanfaatkan lansia adalah keterampilan manual, ramuan jadi dan ramuan buatan sendiri. Lansia laki-laki $(55,5 \%)$ di perkotaan $(56,5 \%)$ lebih banyak memanfaatkan ramuan jadi, sedangkan lansia perempuan $(43,6 \%)$ di perdesaan $(46,5 \%)$ lebih menyukai ramuan buatan sendiri. Lansia dengan tingkat pengeluaran rendah cenderung memanfaatkan ramuan jadi atau ramuan buatan sendiri, sedangkan pengeluaran tinggi cenderung memanfaatkan ketrampilan manual. Penyehat tradisional (98,2\%) adalah jenis tenaga terbanyak dimanfaatkan lansia. Kesimpulan, Yankestrad di Indonesia lebih banyak dimanfaatkan oleh lansia, oleh karena itu berpotensi untuk dikembangkan sebagai alternatif model pelayanan kesehatan bagi lansia. Rekomendasi, mengingat tingginya minat para lansia dengan Yankestrad dan pemanfaatan penyehat tradisional, maka diperlukan penyediaan fasilitas Yankestrad khususnya di Puskesmas dengan tenaga kesehatan tradisional yang mampu memberikan pelayanan kesehatan yang aman dan berkualitas bagi para lansia.
\end{abstract}

Kata Kunci : Yankestrad, lansia, Toga, ramuan buatan sendiri, penyehat tradisional

\begin{abstract}
One of the health efforts that have the opportunity to improve the health status of the elderly is traditional health services (Yankestrad). This paper aims to describe the use of Yankestrad among the elderly in Indonesia. The data source in this analysis is Riskesdas 2018, a research conducted by the Ministry of Health with the elderly ( $\geq 60$ years) as the analysis unit. Data were analyzed descriptively. The results showed that the use of Yankestrad in the elderly was $37.0 \%$ and self-medication with traditional medicine was $17.3 \%$. Young elderly people mostly use Yankestrad (37.9\%), while self-medication with traditional medicine are dominated by elderly women (18.3\%) in rural areas (19.5\%). The use of Toga in the elderly in Indonesia (31.9\%), mostly women (33.3\%) in rural areas (36.3\%). The most common types of Yankestrad used by the elderly were manual skills, potions, and homemade potions. Male elderly (55.5\%) in urban areas
\end{abstract}

Korespondensi:

Rukmini

UPF Inovasi Teknologi Kesehatan, Puslitbang Humaniora dan Manajemen Kesehatan

E - mail : imas_yatno@yahoo.co.id 
(56.5\%) used more prepared ingredients, while female elderly (43.6\%) in rural areas (46.5\%) preferred homemade ingredients. Older people with low expenditure levels tend to take advantage of prepared ingredients or homemade ingredients, while high expenditures tend to take advantage of manual skills. Traditional healers (98.2\%) are the type of yakestrad used mostly by the elderly. In conclusion, Yankestrad in Indonesia is mostly used by the elderly, therefore it has the potential to be developed as an alternative model of health services for the elderly. Given the high interest of the elderly with Yankestrad and the use of traditional healers, it is necessary to provide Yankestrad facilities, especially in Puskesmas with traditional health workers who are able to provide safe and quality health services to the elderly.

Key Word : traditional health services, the elderly, Toga, homemade ingredients, traditional healers.

\section{PENDAHULUAN}

Pembangunan nasional berhasil jika dibuktikan dengan peningkatan usia harapan hidup sebagai dampak perbaikan kualitas kesehatan masyarakat, yang ditunjukkan dengan peningkatan jumlah penduduk lanjut usia (lansia). Menurut undangundang No. 13 Tahun 1998 tentang Kesejahteraan Lanjut Usia, penduduk lanjut usia adalah penduduk berumur 60 tahun ke atas (Republik Indonesia, 1998). Kebijakan pelayanan kesehatan lansia mengacu pada Permenkes No. 25 Tahun 2016 tentang Rencana Aksi Sosial Kesehatan Lanjut Usia Tahun 2016 - 2019, mengandung prinsipprinsip dalam mewujudkan lanjut usia sehat, mandiri, aktif dan produktif (Kementerian Kesehatan RI, 2016) .

Proses penuaan adalah proses alamiah di mana sel-sel tubuh mengalami penurunan dalam fungsinya. Penurunan fungsi organ juga disebabkan karena penyakit degeneratif yang banyak dialami oleh lansia. Sejalan dengan peningkatan usia harapan hidup, semakin kompleks pula masalah kesehatan yang dihadapi (Suiroaka, 2012). Data Riskesdas 2018 menunjukkan prevalensi penyakit tidak menular semakin meningkat pada penduduk kelompok umur lebih dari 55 tahun seperti asma, stroke, hipertensi, gagal ginjal, diabetes mellitus, cedera dan penyakit sendi (Balitbangkes Kemenkes RI, 2019). Salah satu upaya kesehatan yang berpeluang untuk meningkatkan status kesehatan lansia adalah pelayanan kesehatan tradisional (Yankestrad). Upaya tersebut sejalan dengan Renstra Kemenkes Tahun 2015-2019, yang mengembangkan integrasi pelayanan kesehatan tradisional dalam fasilitas pelayanan kesehatan di puskesmas melalui peningkatan kemampuan tenaga kesehatan, optimalisasi penapisan, dan pemberdayaan masyarakat melalui asuhan mandiri di bidang kesehatan tradisional (Kementerian Kesehatan RI, 2015). Strategi kesehatan lansia yang bisa dikembangkan adalah pemberdayaan lansia dalam kesehatan dan kesejahteraan keluarga dan masyarakat melalui pemanfaatan asuhan mandiri obat tradisional.

Di Indonesia, minat masyarakat terhadap pelayanan kesehatan tradisional cukup tinggi dan mempunyai kecenderungan meningkat dari tahun ketahun. Data Riskesdas menunjukan peningkatan proporsi rumah tangga yang pernah memanfaatkan Yankestrad yaitu 30,1\% (2013) dan 31,4\% (2018) (Balitbangkes Kemenkes RI, 2019). Undangundang No. 36 tahun 2009 tentang kesehatan menjelaskan Yankestrad adalah pengobatan dan/atau perawatan dengan cara dan obat berdasarkan pengalaman dan keterampilan turun temurun secara empirik, yang dapat dipertanggungjawabkan, dan diterapkan sesuai dengan norma yang berlaku di masyarakat (Republik Indonesia, 2009). Peraturan Pemerintah nomor 103 Tahun 2014 tentang Pelayanan Kesehatan Tradisional menyebutkan, cara pengobatan atau perawatan yankestrad yaitu 1)Ramuan, baik ramuan kemasan maupun ramuan buatan sendiri; 2)Keterampilan manual, misalnya pijat urut, refleksi, akupresur; 3)Keterampilan olah pikir, misalnya hipnoterapi; 4)Keterampilan energi, misalnya tenaga dalam dan prana (Republik Indonesia, 2014).

Penelitian Rukmini dkk, Yankestrad mempunyai potensi untuk mengatasi permasalahan kesehatan lansia karena 1) Metode Yankestrad relatif aman dan efek samping ringan untuk pengobatan dan pemeliharaan dalam jangka panjang pada lansia dengan penyakit degeneratif, selama dilakukan tenaga kesehatan tradisional (Nakestrad) profesional; 2) Metode Yankestrad 
dapat mengurangi beban polifarmasi pada lansia; 3) Yankestrad dengan latar belakang budaya, akan lebih mudah diterima di kalangan lansia; 4) Yankestrad bersifat promotif dan preventif, berperan sebagai penunjang pengobatan konvensional sehingga pelayanan bisa dilakukan secara holistik (Rukmini et al., 2019). Mempertimbangkan latar belakang tersebut, maka dilakukan analisis untuk mengetahui gambaran pemanfaatan Yankestrad pada penduduk lansia di Indonesia. Informasi ini bermanfaat sebagai masukan program untuk pengembangan pelayanan kesehatan lansia dan upaya pemberdayaan lansia untuk peningkatan kesehatan keluarga dan masyarakat.

\section{METODE}

Tulisan ini merupakan analisis lanjut data Riskesdas 2018, yang merupakan penelitian dengan desain potong lintang dan kerangka sampel Blok Sensus (BS) Susenas BPS bulan Maret 2018. Populasi Riskesdas adalah rumah tangga di Indonesia, mencakup seluruh provinsi dan kabupaten/kota yaitu 34 Provinsi, 416 kabupaten dan 98 kota.

Analisis ini bertujuan untuk mengidentifikasi pemanfaatan pelayanan kesehatan tradisional pada lansia di Indonesia. Variabel analisis meliputi: 1) Pemanfaatan Yankestrad pada Penduduk lansia; 2) Pemanfaatan TOGA pada Penduduk lansia; 3) Jenis Yankestrad yang dimanfaatkan pada Penduduk lansia; 4) Jenis tenaga yang dimanfaatkan untuk menangani kesehatan tradisional. Analisis data secara deskriptif menurut provinsi dan karateristik penduduk lansia di Indonesia.

HASIL

\section{Penduduk Lanjut Usia di Indonesia}

Gambar 1 menunjukkan secara nasional di Indonesia proporsi lansia sebesar 35\%, sedangkan DI Yogyakarta mempunyai lansia yang terbanyak sebesar $41,4 \%$ dan yang terendah adalah Papua Barat sebesar $18,4 \%$.

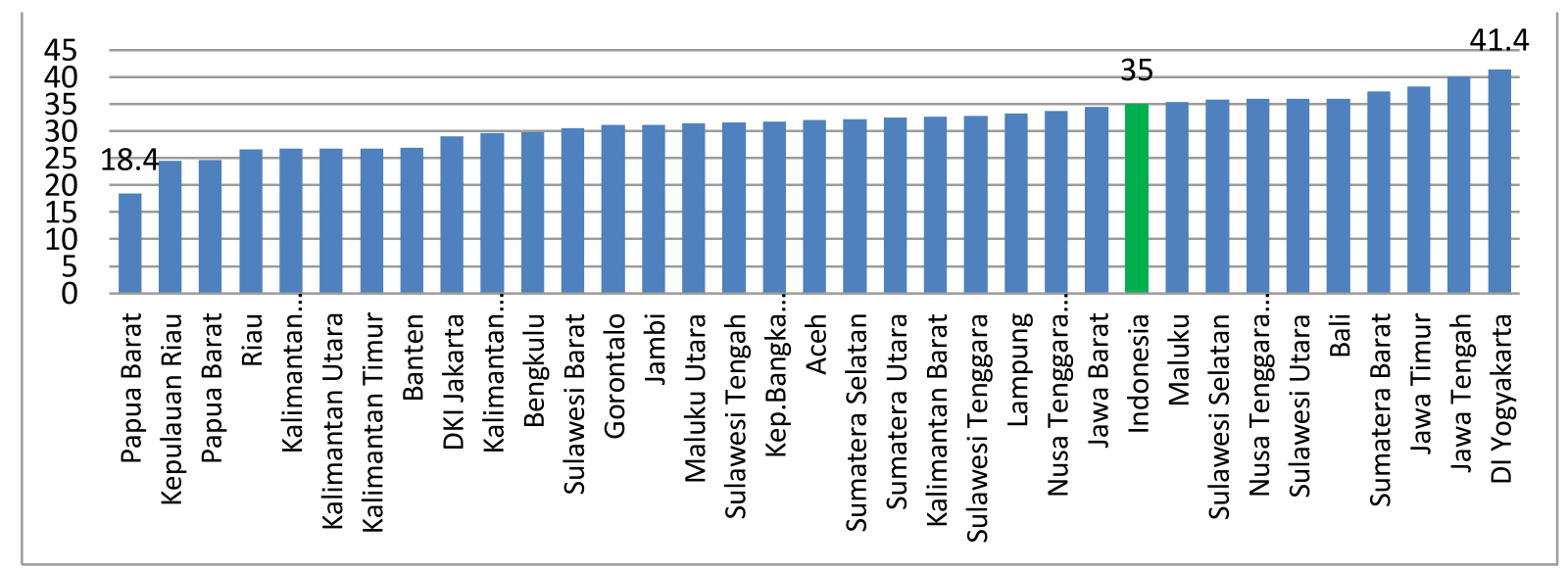

\section{Gambar 1. Proporsi Penduduk Lansia menurut Propinsi di Indonesia, Tahun 2018. Sumber : Data Riskesdas 2018}

\section{Pemanfaatan Pelayanan Kesehatan Tradisional pada Penduduk Lansia}

Gambar 2 menunjukkan proporsi pemanfaatan Yankestrad oleh lansia, secara nasional sebanyak $37,0 \%$ Lansia memanfaatkan Yankestrad dan $17,3 \%$ melakukan upaya sendiri dalam menggunakan obat tradisional. Pemanfaatan Yankestrad pada lansia yang tertinggi di Propinsi
Kalimantan Selatan sebesar $59,3 \%$, sedangkan terendah adalah Sulawesi Barat sebesar 10,1\%. Lansia dengan upaya sendiri dengan obat tradisional, yang tertinggi di Propinsi Sulawesi Barat sebesar $36,5 \%$, sedangkan terendah adalah Bengkulu (10,7\%).

Berdasarkan karakteristiknya (Tabel 1), lansia muda $(37,9 \%)$ adalah kelompok tertinggi yang 


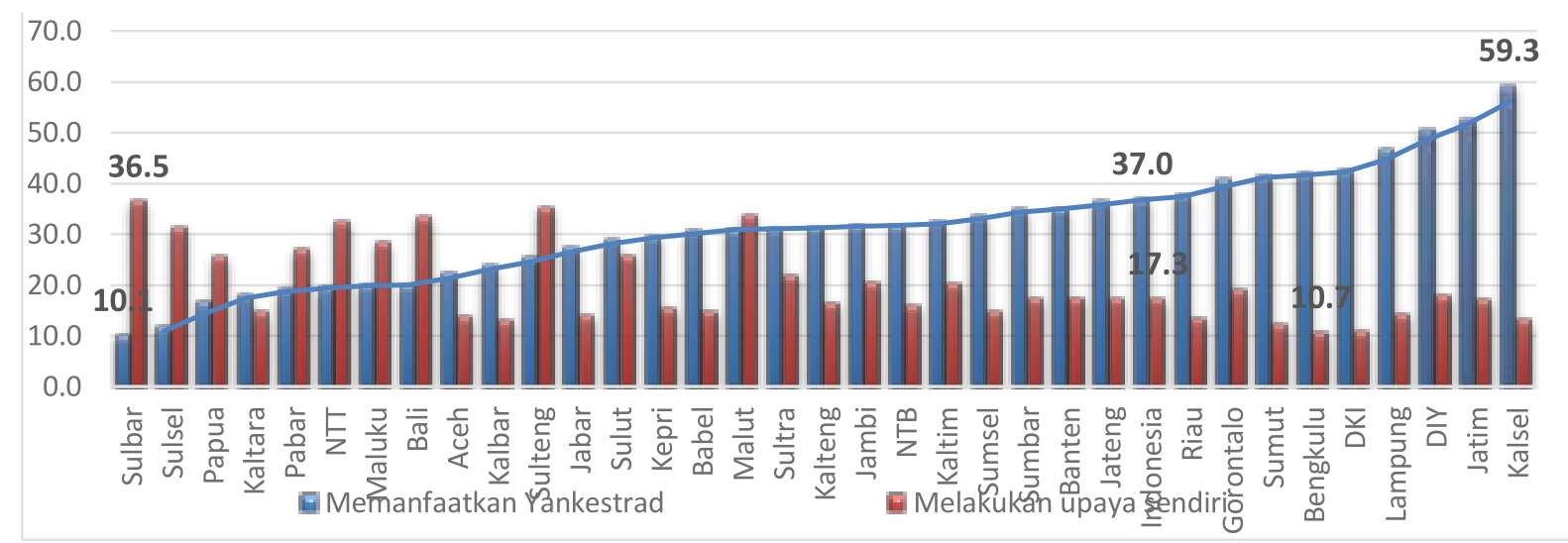

\section{Gambar 2. Proporsi Pemanfaatan Pelayanan Kesehatan Tradisional pada Penduduk Lansia menurut Provinsi di Indonesia, Tahun 2018. Sumber : Data Riskesdas 2018}

memanfaatkan Yankestrad, sedangkan upaya sendiri didominasi lansia perempuan $(18,3 \%)$ dan tinggal di perdesaan (19,5\%). Berdasarkan pendidikan lansia, relatif sebanding dalam memanfaatkan yankestrad, sedangkan melakukan upaya sendiri cenderung lebih tinggi pada pendidikan rendah (tidak tamat SD/MI atau tidak sekolah). Jenis pekerjaan nelayan cenderung lebih tinggi dalam pemanfaatan Yankestrad $(40,5 \%)$, sedang upaya sendiri lebih banyak pada petani/buruh tani $(19,8 \%)$. Berdasarkan pengeluaran, pemanfaatan Yankestrad cenderung sama, sedangkan melakukan upaya sendiri cenderung lebih tinggi pada tingkat pengeluaran terendah (kuintil 1).
3. Jenis Pelayanan Kesehatan Tradisional yang Dimanfaatkan pada Penduduk Lansia

Gambar 3 menunjukkan, di Indonesia jenis yankestrad terbanyak yang dimanfaatkan lansia berturut-turut adalah keterampilan manual $(58,8 \%)$, ramuan jadi $(53,9 \%)$, ramuan buatan sendiri $(41,8 \%)$, keterampilan energi $(2 \%)$ dan keterampilan olah pikir $(1,9 \%)$. Propinsi dengan pemanfaatan tertinggi keterampilan manual adalah Kalimantan Selatan $(81,4 \%)$, ramuan jadi adalah Jawa Tengah (64\%), ramuan buatan sendiri adalah Sulawesi Barat $(92,2 \%)$, keterampilan energi adalah Nusa Tenggara Barat (5,9\%) dan keterampilan olah pikir adalah Bangka Belitung $(4,5 \%)$.

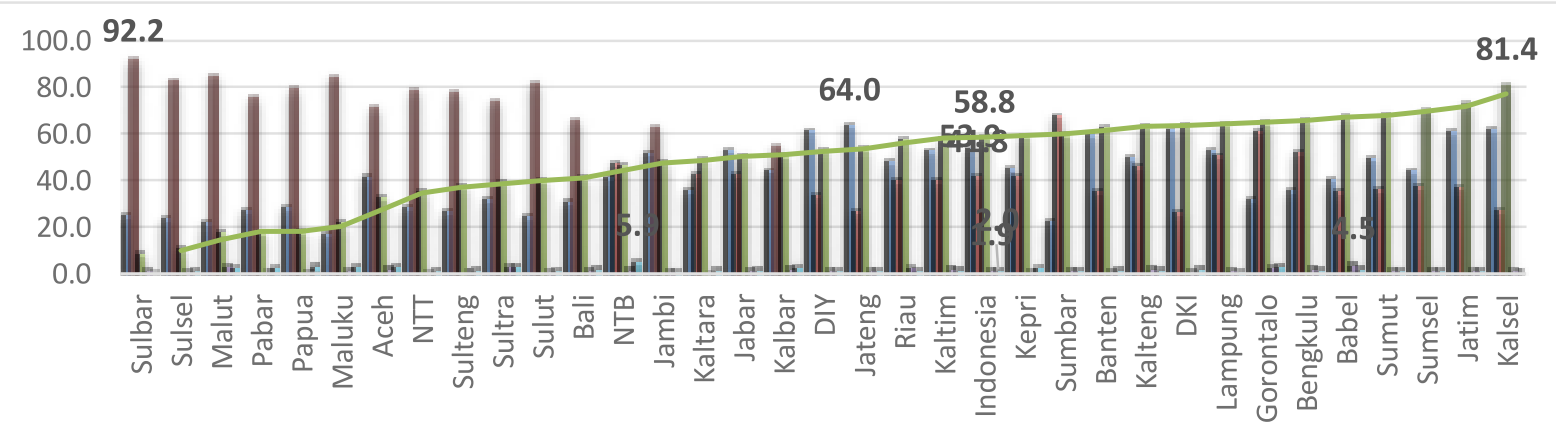

ERamuan Jadi $\mathbf{E}$ Ramuan buatan sendiri $\mathbf{E}$ Keterampilan manual $\mathbf{E}$ Keterampilan olah pikir $\mathbf{E}$ Keterampilan energi

Gambar 3. Proporsi Jenis Pelayanan Kesehatan Tradisional yang Dimanfaatkan pada Penduduk Lansia menurut Provinsi di Indonesia, Tahun 2018.

Sumber : Data Riskesdas 2018 
Secara karakteristik (Tabel 1), kelompok umur dan pekerjaan lansia mempunyai kecenderungan yang relatif sebanding dalam memanfaatkan Yankestrad. Lansia yang bertempat tinggal di perkotaan $(56,5 \%)$ dan laki-laki $(55,5 \%)$, lebih banyak memanfaatkan ramuan jadi, sedangkan lansia perempuan $(43,6 \%)$ di perdesaan $(46,5 \%)$, lebih menyukai menggunakan ramuan buatan sendiri. Menurut tingkat pengeluaran, semakin kecil pengeluaran, ada kecenderungan lansia untuk semakin memanfaatkan yankestrad ramuan jadi atau ramuan buatan sendiri, sedangkan semakin besar pengeluaran, lansia cenderung makin banyak memanfaatkan Yankestrad jenis ketrampilan manual.

\section{Jenis Tenaga Yang Dimanfaatkan Untuk Menangani Kesehatan Tradisional}

Gambar 4 menunjukkan sebagian besar lansia memanfatkan penyehat tradisional (98,2\%) dibandingkan dokter/tenaga kesehatan (nakes) $(3,4 \%)$. Propinsi dengan pemanfaatan tertinggi untuk dokter/nakes adalah Sulawesi Selatan $(12,4 \%)$ dan terendah Banten (1,2\%). Pemanfaatan penyehat tradisional tertinggi di Kalimantan Utara $(100 \%)$, sedang terendah di Sulawesi Barat $(90,9 \%)$.

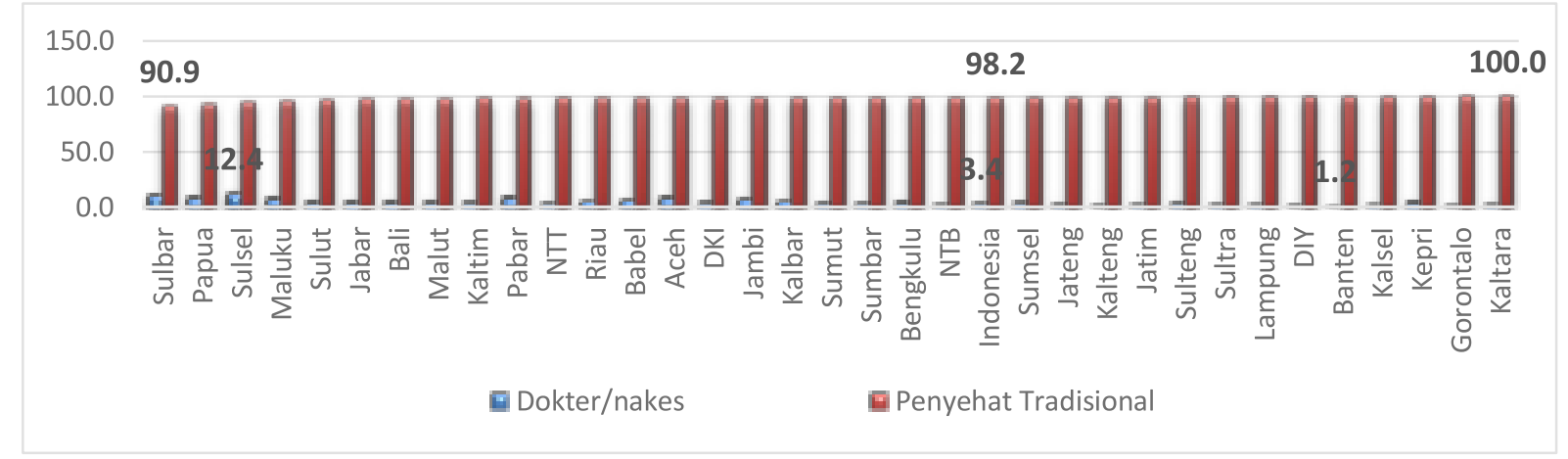

\section{Gambar 4. Proporsi Jenis Tenaga yang Dimanfaatkan Menangani Kesehatan Tradisional pada Penduduk Lansia menurut Provinsi di Indonesia, Tahun 2018.} Sumber : Data Riskesdas 2018

Dominasi pemanfaatan penyehat tradisional oleh lansia ditemukan pada semua karakteristik baik kelompok umur, tempat tinggal, jenis kelamin, pendidikan, pekerjaan dan tingkat pengeluaran
(Tabel 1). Pemanfaaan dokter/nakes, cenderung lebih tinggi pada PNS/TNI/Polri/BUMN/BUMD $(6,4 \%)$ dan tingkat pengeluaran tinggi (kuintil 5) sebesar $4,6 \%$.

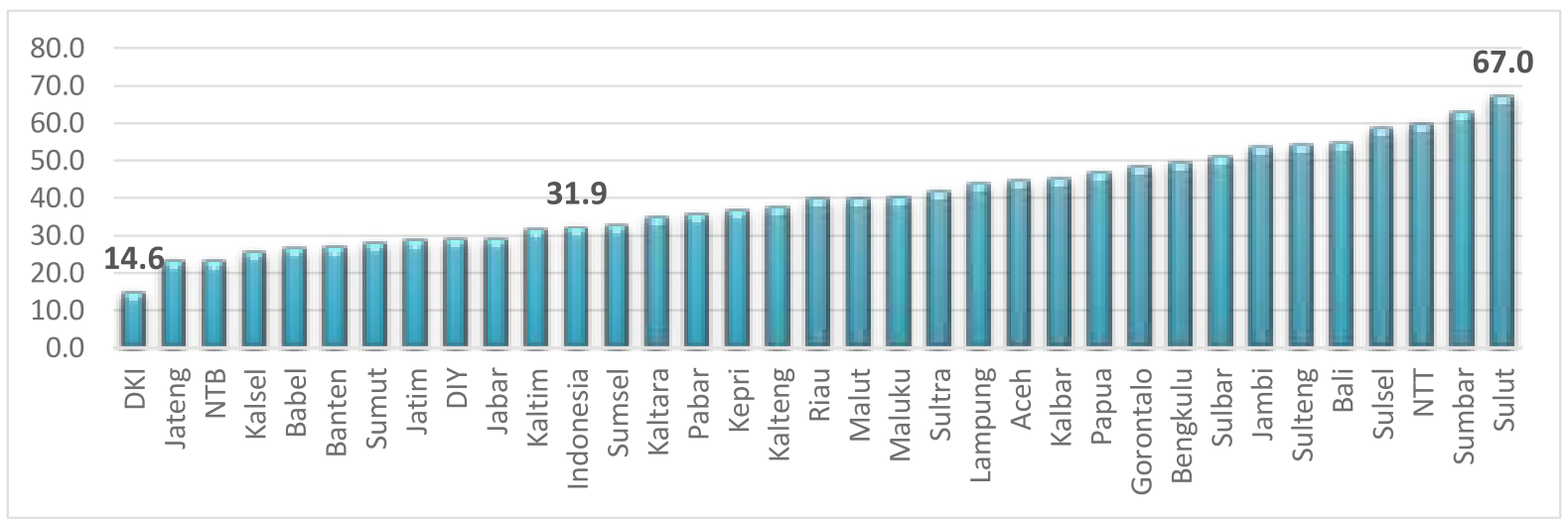

Gambar 5. Proporsi Pemanfaatan TOGA pada Penduduk Lansia menurut Provinsi di Indonesia, Tahun 2018.

Sumber : Data Riskesdas 2018 


\section{Pemanfaatan TOGA pada Penduduk Lansia}

Gambar 5 menunjukkan proporsi pemanfaatan Toga oleh lansia, secara nasional sebesar 31,9\%, pemanfaatan yang tertinggi di Propinsi Sulawesi Utara sebesar $67,0 \%$, sedangkan yang terendah adalah DKI Jakarta (14,6\%).

Berdasarkan karateristik, pemanfaatan yankestrad oleh lansia yaitu Lansia muda memiliki proporsi tertinggi yang memanfaatkan yankestrad $(37,9 \%)$. Lansia yang melakukan upaya sendiri didominasi lansia yang tinggal di perdesaan $(19,5 \%)$ dan berjenis kelamin perempuan $(18,3 \%)$. Lansia yang memanfaatkan yankestrad sebanding antara lansia di perkotaan dan perdesaan serta antara laki-laki dan perempuan. Pendidikan lansia, tidak mempengaruhi kecenderungan dalam memanfaatkan yankestrad dan melakukan upaya sendiri. Tingkat pengeluaran juga tidak mempengaruhi kecenderungan dalam memanfaatkan yankestrad maupun melakukan upaya sendiri.

Berdasarkan jenis Yankestrad yang dimanfaatka lansia menurut karateristik, ramuan jadi, ramuan buatan sendiri, dan ketrampilan manual merupakan layanan yang paling banyak dimanfaatkan. Karakteristik kelompok umur dan pekerjaan tidak banyak mempengaruhi kecenderungan lansia dalam memanfaatkan yankestrad. Lansia yang bertempat tinggal di perkotaan $(56,5 \%)$ dan lansia laki-laki $(55,5 \%)$ lebih banyak memanfaatkan ramuan jadi, sedang yang di perdesaan $(46,5 \%)$ dan berjenis kelamin perempuan $(43,6 \%)$ lebih menyukai menggunakan ramuan buatan sendiri. Berdsarkan tingkat pengeluaran, semakin kecil tingkat pengeluaran (kuintil 1), ada kecenderungan lansia untuk semakin memanfaatkan yankestrad ramuan jadi atau ramuan buatan sendiri. Sebaliknya, semakin besar tingkat pengeluaran (kuintil 5), lansia cenderung makin banyak memanfaatkan yankestrad pada jenis ketrampilan manual.

Karateristik jenis tenaga yang dimanfaatkan untuk menangani kesehatan tradisional oleh lansia, didominasi oleh penyehat tradisional $(98,2 \%)$ dibandingkan dokter atau tenaga kesehatan lainnya. Dominasi penyehat tradisional ini terlihat pada semua karakteristik baik kelompok umur, tempat tinggal, jenis kelamin, Pendidikan, pekerjaan dan tingkat pengeluaran.

Karakteristik pemanfaatan TOGA pada lansia di Indonesia, cenderung lebih tinggi pada Lansia muda (60 - 69 tahun), perempuan (33,3\%), tinggal di perdesaan $(36,3 \%)$, berpendidikan tinggi (tamat D1/D2/D3/PT) 38,2\%, pekerjaan PNS/TNI/Polri/ BUMN/BUMD (37\%) dan pada tingkat pengeluaran rendah (kuintil 1) sebesar 32,6\% (Tabel 1).

Tabel 1. Proporsi Pemanfaatan Yankestrad, Jenis Yankestrad yang Dimanfaatkan, Jenis Tenaga yang Dimanfaatan, dan Pemanfaatan TOGA pada Penduduk Lanjut Usia menurut Karateristik di Indonesia, Riskesdas 2018.

\begin{tabular}{|c|c|c|c|c|c|c|c|c|c|c|}
\hline \multirow{3}{*}{ Karakteristik } & \multicolumn{2}{|c|}{ Pemanfaatan Yankestrad } & \multicolumn{5}{|c|}{ Jenis Yankestrad yang Dimanfaatkan } & \multicolumn{2}{|c|}{$\begin{array}{l}\text { Jenis Tenaga yang } \\
\text { Dimanfaatkan }\end{array}$} & \multirow{2}{*}{$\begin{array}{c}\text { Pernah } \\
\text { memanfaat } \\
\text { kan TOGA }\end{array}$} \\
\hline & $\begin{array}{l}\text { Memanfaat } \\
\text { kan }\end{array}$ & $\begin{array}{l}\text { Melakukan } \\
\text { upaya } \\
\text { sendiri }\end{array}$ & $\begin{array}{l}\text { Ramuan } \\
\text { Jadi }\end{array}$ & $\begin{array}{c}\text { Ramuan } \\
\text { buatan } \\
\text { sendiri }\end{array}$ & $\begin{array}{c}\text { Keterampilan } \\
\text { manual }\end{array}$ & $\begin{array}{l}\text { Keterampilan } \\
\text { olah pikir }\end{array}$ & $\begin{array}{l}\text { Keterampilan } \\
\text { energi }\end{array}$ & $\begin{array}{c}\text { Dokterl } \\
\text { nakes }\end{array}$ & $\begin{array}{l}\text { Penyehat } \\
\text { Tradisional }\end{array}$ & \\
\hline & $(\%)$ & $(\%)$ & $(\%)$ & $(\%)$ & $(\%)$ & $(\%)$ & $(\%)$ & $(\%)$ & $(\%)$ & $(\%)$ \\
\hline \multicolumn{11}{|l|}{ Kelompok umur } \\
\hline Lansia Muda (60 - 69 th) & 37,9 & 17,3 & 53,5 & 41,7 & 60,1 & 1,8 & 2,0 & 3,2 & 98,3 & 32,1 \\
\hline Lansia Madya (70 - 79 th) & 36,4 & 17,4 & 54,5 & 42,2 & 56,2 & 1,9 & 2,0 & 3,9 & 97,8 & 31,6 \\
\hline Lansia Tua (> 80 th) & 32,3 & 16,9 & 55,4 & 40,8 & 56,6 & 2,2 & 2,2 & 3,4 & 98,3 & 31,7 \\
\hline \multicolumn{11}{|l|}{ Tempat tinggal } \\
\hline Perkotaan & 37,3 & 15,2 & 56,5 & 36,8 & 58,8 & 1,9 & 2,1 & 3,6 & 97,9 & 27,4 \\
\hline Perdesaan & 36,7 & 19,5 & 51,4 & 46,5 & 58,7 & 1,8 & 2,0 & 3,1 & 98,4 & 36,3 \\
\hline \multicolumn{11}{|l|}{ Jenis Kelamin } \\
\hline Laki-laki & 36,6 & 16,2 & 55,5 & 39,5 & 60,2 & 2,2 & 2,3 & 3,7 & 98,0 & 30,2 \\
\hline Perempuan & 37,4 & 18,3 & 52,6 & 43,6 & 57,5 & 1,6 & 1,8 & 3,1 & 98,4 & 33,3 \\
\hline \multicolumn{11}{|l|}{ Pendidikan } \\
\hline $\begin{array}{l}\text { Tidak/belum pernah } \\
\text { sekolah }\end{array}$ & 37,9 & 18,8 & 58,0 & 41,0 & 57,3 & 1,9 & 1,7 & 2,6 & 98,6 & 29,8 \\
\hline Tidak tamat SD/MI & 38,1 & 18,2 & 55,2 & 43,0 & 57,6 & 1,6 & 1,7 & 3,1 & 98,4 & 31,0 \\
\hline Tamat SD/Ml & 35,7 & 17,4 & 53,7 & 42,7 & 58,6 & 2,0 & 2,4 & 3,6 & 98,1 & 33,4 \\
\hline Tamat SLTP/MTs & 37,8 & 14,8 & 49,3 & 40,3 & 61,3 & 1,9 & 1,8 & 5,1 & 97,0 & 32,7 \\
\hline Tamat SLTAIMA & 35,6 & 13,5 & 48,0 & 38,2 & 61,9 & 2,0 & 2,7 & 4,2 & 97,6 & 31,8 \\
\hline Tamat D1/D2/D3/PT & 36,7 & 15,6 & 43,8 & 38,7 & 65,6 & 2,5 & 2,9 & 3,4 & 98,3 & 38,2 \\
\hline
\end{tabular}




\begin{tabular}{|c|c|c|c|c|c|c|c|c|c|c|}
\hline \multicolumn{11}{|l|}{ Pekerjaan } \\
\hline Tidak bekerja & 35,7 & 16,5 & 53,1 & 41,4 & 57,1 & 1,7 & 2,1 & 3,7 & 98,0 & 31,6 \\
\hline Sekolah & 37,2 & 19,2 & 40,7 & 51,0 & 59,7 & 4,1 & 6,6 & 3,9 & 100,0 & 34,7 \\
\hline PNS/TNI/Polri/BUMN/BUM D & 34,6 & 17,2 & 45,6 & 42,2 & 60,6 & 3,3 & 3,6 & 6,4 & 97,7 & 37,0 \\
\hline Pegawai swasta & 36,5 & 12,0 & 57,7 & 30,0 & 63,1 & 3,7 & 2,7 & 3,7 & 97,1 & 22,1 \\
\hline Wiraswasta & 39,7 & 14,8 & 56,1 & 35,7 & 65,4 & 1,5 & 2,0 & 3,4 & 98,2 & 25,8 \\
\hline Petani/buruh tani & 38,6 & 19,8 & 54,2 & 45,2 & 59,1 & 2,0 & 1,8 & 3,1 & 98,4 & 35,3 \\
\hline Nelayan & 40,5 & 17,8 & 56,2 & 51,5 & 58,6 & 1,2 & 1,9 & 3,7 & 97,9 & 24,0 \\
\hline Buruh/sopir/pembantu ruta & 36,4 & 16,0 & 60,6 & 35,5 & 55,9 & 2,0 & 1,6 & 2,2 & 98,6 & 24,7 \\
\hline Lainnya & 35,3 & 16,9 & 50,3 & 41,8 & 59,4 & 1,8 & 2,7 & 2,9 & 98,4 & 33,9 \\
\hline \multicolumn{11}{|l|}{ Tingkat pengeluaran } \\
\hline Kuintil 1 & 35,8 & 19,0 & 55,3 & 44,4 & 55,8 & 1,7 & 1,8 & 2,9 & 98,2 & 32,6 \\
\hline Kuintil 2 & 37,4 & 17,9 & 56,2 & 43,1 & 57,4 & 1,9 & 1,9 & 3,1 & 98,4 & 32,2 \\
\hline Kuintil 3 & 37,0 & 17,3 & 55,0 & 42,0 & 58,6 & 1,8 & 2,2 & 3,0 & 98,3 & 31,9 \\
\hline Kuintil 4 & 37,6 & 17,0 & 54,1 & 40,3 & 59,2 & 2,0 & 2,1 & 3,2 & 98,3 & 31,5 \\
\hline Kuintil 5 & 37,5 & 15,0 & 48,9 & 38,3 & 63,3 & 2,0 & 2,4 & 4,6 & 97,6 & 31,2 \\
\hline TOTAL & 37,0 & 17,3 & 53,9 & 41,8 & 58,8 & 1,9 & 2,0 & 3,4 & 98,2 & 31,9 \\
\hline
\end{tabular}

Sumber: Data Riskesdas 2018

\section{PEMBAHASAN}

Di Indonesia proporsi lansia sebesar 35\% dari jumlah penduduk, jumlah lansia terbanyak di DI Yogyakarta dan terendah Papua Barat. Hal ini sejalan dengan pencapaian umur harapan hidup (UHH) di Jogjakarta yang tertinggi di Indonesia tahun 2019 sebesar 74,92 tahun, sedangkan UHH secara nasional sebesar 71,34 tahun (BPS RI, 2020).

Pemanfaatan Yankestrad lansia lebih besar dibanding dengan upaya pengobatan tradisional sendiri, hal ini menunjukkan kebutuhan Lansia terhadap penyediaan fasilitas pelayanan dan tenaga kesehatan tradisional, sehingga diperlukan fasilitas Yankestrad yang aman sesuai kebutuhan lansia. Penelitian Handayani menunjukkan kelompok usia diatas 40 tahun, menyatakan persetujuan pengobatan tradisional potensial untuk dikembangkan, memiliki khasiat untuk penyembuhan namun fasilitas pengobatan belum terstandar (Handayani, Puspariki and Nurmala, 2019).

$\mathrm{Di}$ daerah yang ketersediaan fasilitas kesehatan masih minim seperti di Sulawesi Barat, menunjukkan lansia banyak melakukan upaya sendiri dengan obat tradisional. Sebaliknya DKI Jakarta dengan fasilitas Yankestrad cukup tersedia, upaya pengobatan tradisional sendiri juga sangat rendah. Studi Wardani menunjukkan, swamedikasi dengan obat tradisional banyak dilakukan $(81,6 \%)$ dan $83,3 \%$ tidak merasakan efek samping obat. Swamedikasi dengan obat tradisional disukai dibandingkan obat kimia karena tidak menimbulkan efek samping (Supardi and Notosiswoyo, 2005). Faktor yang paling berpengaruh terhadap swamedikasi obat tradisional adalah pengetahuan, kepercayaan dan jarak sarana kesehatan dengan nilai probabilitas 90,93\% (Liana, 2017). Data Indonesia Family Live Survey (IFLS) di 13 provinsi menunjukkan, pengobatan tradisional merupakan pilihan individu dalam rumah tangga yang berusia lanjut, tinggal di desa dan tinggal di wilayah yang terdapat pos obat (Jennifer and Saptutyningsih, 2015). Studi lainnya menemukan tingkat pengetahuan pengguna jamu swamedikasi dikatagorikan baik, dengan skor $>75 \%$ yaitu sebesar 90,1\% (Sugarna, Marini and Nurhayatina, 2019). Kondisi tersebut sejalan dengan penelitian ini, lansia banyak melakukan upaya sendiri dengan obat tradisional untuk mengatasi keluhan kesehatannya.

Penelitian Suharmiati (2020), Yankestrad integrasi telah tersedia di RS dan dilayani dokter, terbanyak dimanfaatkan pasien berusia antara 20-50 tahun dan tinggal tidak jauh dari RS. Sebagian responden merasa puas dengan pelayanannya, tetapi berpendapat bahwa biaya pengobatan Yankestrad mahal karena tidak ditanggung BPJS, namun mereka bersedia berobat dengan biaya sendiri karena Yankestrad merupakan pengobatan yang mereka butuhkan (Suharmiati, Handayani and N, 2020). Kondisi seperti ini membuka peluang agar pelayanan Kesehatan konvensional turut melakukan inovasi untuk memberikan Yankestrad integrasi. Yankestrad integrasi adalah suatu bentuk pelayanan kesehatan yang mengombinasikan pelayanan kesehatan konvensional dengan pelayanan kesehatan tradisional komplementer, baik bersifat sebagai pelengkap maupun pengganti dalam keadaan tertentu, berdasarkan Permenkes 37 tahun 2017. Seperti halnya di Puskesmas Made Kota Surabaya, sudah menyediakan pelayanan kesehatan tradisional bagi lansia sebagai salah satu inovasi yang mendapat apresiasi yang bagus. 
Jenis pelayanan yang tersedia yaitu akupunktur, akupressure dan herbal medik. Kasus terbanyak Yankestrad pada lansia adalah relaksasi, stroke, diabetes mellitus, hipertensi, dan obesitas (Rukmini and Oktarina, 2020).

Berdasarkan karakteristik usia, lansia muda terbanyak memanfaatkan Yankestrad. Semakin tinggi usia lansia, proporsi memanfaatkan Yankestrad semakin menurun pada umumnya lansia mengalami kesulitan mengunjungi faskes tanpa bantuan orang lain. Lansia yang melakukan upaya sendiri dengan obat tradisional didominasi lansia di perdesaan, perempuan, berpendidikan rendah (tidak sekolah dan tidak tamat SD), petani dan pada tingkat pengeluaran terendah. Sejalan dengan Supardi (2010), upaya pengobatan tradisional sendiri lebih besar pada lansia, status menikah, pendidikan rendah, pekerjaan petani, nelayan atau tidak bekerja dan bertempat tinggal di desa (Supardi and Notosiswoyo, 2005; Supardi and Susyanti, 2010). Penelitian Andriati (2016), menunjukkan konsumsi masyarakat terhadap jamu tertinggi pada ekonomi rendah (pendapatan kurang dari 1 juta/bulan), sebesar 58\%, ekonomi menengah (pendapatan antara 1,5-5 jutat/bulan) sebesar $25 \%$, sedangkan ekonomi atas (pendapatan $>5$ juta/bulan) cenderung pada pengobatan farmasi (17\%). Faktor yang berpengaruh terhadap penggunaan jamu sebagai alternatif adalah faktor pribadi, pemasaran, sosial, budaya, psikologi, harga, dan faktor legalitas lembaga kesehatan (rumah sakit dan puskesmas) (Andriyanti and Wahjudi, 2016).

Jenis Yankestrad yang terbanyak dimanfaatkan lansia adalah keterampilan manual, ramuan jadi dan ramuan buatan sendiri. Temuan ini sejalan dengan proporsi jenis pemanfaatan Yankestrad di rumah tangga (Riskesdas 2018), terbanyak ketrampilan manual sebesar $65,3 \%$, ramuan jadi $(48 \%)$ dan ramuan buatan sendiri (31,8\%) (Balitbangkes Kemenkes RI, 2019). Hasil menunjukkan proporsi pemanfaatan ramuan jadi dan buatan sendiri pada lansia lebih tinggi daripada di rumah tangga. Kondisi ini membuktikan peningkatan minat penduduk menggunakan ramuan sendiri, dibandingkan 10 tahun yang lalu, sesuai penelitian Supardi (2011), menemukan rumah tangga yang menggunakan jamu buatan sendiri sebesar 9,53\% (Supardi, Herman and Yuniar, 2011). Studi Aprillia (2020), proporsi terbesar pemanfaatan Yankestrad dan ramuan jadi adalah lansia tinggal di kota, sedangkan upaya sendiri dan membuat ramuan sendiri tinggal di desa dan berhubungan status sosial ekonomi (Aprilla,
2020). Hasil penelitian menunjukkan lansia memiliki cara perilaku pencarian pengobatan yang bergantung pengobatan medis, tradisional dan herbal (Nandatia, Xaverius And Sadewo, 2019). Perilaku pencarian pengobatan penyakit hipertensi pada lansia, selain dengan obat kimia juga dengan obat tradisional yang diramu sendiri seperti mentimun, bawang putih, daun seledri, daun belimbing dsb (Fatonah and Hernawilly, 2012). Studi Stefani (2020) menunjukan peningkatan kemampuan swamedikasi obat tradisional pada lansia untuk mengobati Diabetes Melitus, Hipertensi dan asam Urat dengan pemberian penyuluhan, bibit tanaman obat dan modul pengolahan tanaman obat (Stefani et al., 2020). Kebiasaan konsumsi jamu di masyarakat dipengaruhi sikap terhadap jamu, merupakan faktor dominan untuk meningkatkan kebiasaan konsumsi jamu secara rutin $(23,262 x)$ dibandingkan tingkat pengetahuan $(1,273 x)$ (Kusuma et al., 2020).

Lansia laki-laki di perkotaan, lebih banyak memanfaatkan ramuan jadi, sedangkan ramuan buatan sendiri terbanyak pada lansia perempuan di perdesaan. Kondisi ini karena di kota lebih mudah ramuan siap beli, minimnya lahan untuk menanam TOGA serta laki-laki relatif kurang telaten menyiapkan ramuan sendiri. Salah satu bentuk ramuan jadi yang dijual adalah dalam bentuk simplisia. Penelitian Putri (2018) menunjukkan beberapa simplisia memiliki akurasi untuk penyakit demam, diare dan batuk berkisar 40\%-50\%. Simplisia tersebut adalah daun asem, buah cabe jawa, daun beluntas, rimpang alang-alang, kulit buah delima putih, daun jungrahap, kayu manis, kayu secang, kapulaga dan kulit kapulasari (Putri Lailil; Adinugroho, Sigit, 2018). Penelitian Kartikasari menemukan ramuan jadi berupa parem kocok yang mengandung kencur, kunir putih dan daun pacar air terbukti menurunkan nyeri sendi pada lansia (Kartikasari Ellia, 2018). Kondisi ini yang turut membuat orang tetap memanfaatkan ramuan jadi.

Riset menunjukkan terdapat pengaruh budaya, persepsi, dan kepercayaan terhadap keputusan pembelian obat herbal. Penggunaan obat herbal berdasarkan budaya yang diyakini (43,18\%), persepsi obat herbal terjamin $(52,7 \%)$, cepat sembuhnya $(35,4 \%)$, berkhasiat $(48,7 \%)$, dan terbukti menyembuhkan $(29,8 \%)$ dan kepercayaan obat herbal berkhasiat $(59,5 \%)$, kandungannya bagus $(44,6 \%)$, menyembuhkan $(43,2 \%)$ (Marwati and Amidi, 2019).

Lansia di Indonesia terbanyak memanfatkan penyehat tradisional $(98,2 \%)$, dibandingkan 
dokter/nakes $(3,4 \%)$. Hasil ini tidak jauh berbeda dengan proporsi pemafaatan jenis tenaga Yankestrad di rumah tangga yaitu penyehat tradisional $(98,5 \%)$ dan tenaga kesehatan tradisional $(2,7 \%)$ (Balitbangkes Kemenkes RI, 2019). Kondisi tersebut karena keberadaan penyehat tradisional lebih tersedia, waktu pelayanan lebih fleksibel dan biaya terjangkau. Oleh karena itu penyediaan tenaga kesehatan tradisional (Nakestrad) masih sangat dibutuhkan. Nakestrad adalah tenaga kesehatan yang ilmu dan keterampilannya diperoleh melalui pendidikan tinggi di bidang kesehatan paling rendah diploma (Republik Indonesia, 2014).

Di Indonesia pemanfaatan TOGA oleh lansia sebesar 31,9\%, tertinggi di Propinsi Sulawesi Utara $(67,0 \%)$ dan terendah DKI Jakarta (14,6\%). Riskesdas 2018 menunjukkan rumah tangga yang memanfaatkan Yankestrad sebesar 31,4\%, sedangkan Tanaman Obat Keluarga (TOGA) sebesar $24,6 \%$, tertinggi di Sulawesi Utara $(55,6 \%)$ (Balitbangkes Kemenkes RI, 2019). Menurut Kinho (2011) dalam Aprillia (2020) masyarakat tradisional di Sulawesi Utara yang bermukim di sekitar kawasan hutan telah banyak memanfaatkan sumberdaya hutan khususnya tumbuhan untuk memenuhi kebutuhan obat-obatan tradisional. Pengetahuan mengenai pengobatan secara tradisional diwariskan secara turun temurun, terutama yang bahan bakunya berasal dari alam telah dikenal sejak zaman purba di Tanah Minahasa (Aprilla, 2020). Studi Ariastuti (2109) menunjukan, masyarakat telah memanfaatkan sebagian pekarangan rumah untuk ditanamani TOGA yang bertujuan preventif, kuratif, dan promotif untuk mengatasi penyakit ringan seperti batuk, flu, diare dan sakit kepala dengan alasan murah, mudah didapat dan alami (Ariastuti and Herawati, 2019). Kegiatan pembinaan Asuhan Mandiri Tanaman Obat Keluarga dan Akupresur terhadap kelompok kader di Puskesmas berjalan dengan baik. (Imandiri and Septriana, 2019). Tanaman Toga juga dimanfaatkan oleh masyarakat untuk mengatasi penyakit hipertensi (Prasetyani and Andika, 2019; Vera and Yanti, 2020)

\section{KESIMPULAN DAN SARAN}

\section{Kesimpulan}

Pemanfaatan Yankestrad pada lansia 37,0\% dan upaya sendiri dengan obat tradisional $(17,3 \%)$. Lansia muda terbanyak memanfaatkan Yankestrad, sedangkan upaya sendiri didominasi lansia perempuan di perdesaan. Pemanfaatan Toga pada lansia di Indonesia (31,9\%), tertinggi di Propinsi Sulawesi Utara, dengan karateristik lansia terbanyak perempuan di perdesaan. Jenis layanan terbanyak adalah keterampilan manual (tertinggi di Kalimantan Selatan), ramuan jadi (tertinggi di Jawa Tengah) dan ramuan buatan sendiri (tertinggi di Sulawesi Barat). Lansia laki-laki di perkotaan lebih banyak memanfaatkan ramuan jadi, sedangkan lansia perempuan di perdesaan lebih menyukai ramuan buatan sendiri. Lansia dengan tingkat pengeluaran rendah cenderung memanfaatkan ramuan jadi atau ramuan buatan sendiri, sedangkan pengeluaran tinggi cenderung memanfaatkan ketrampilan manual. Penyehat tradisional $(98,2 \%)$ adalah jenis tenaga terbanyak dimanfaatkan oleh lansia.

\section{Saran}

Mempertimbangkan tingginya minat lansia terhadap Yankestrad dan pemanfaatan penyehat tradisional, diperlukan penyediaan fasilitas Yankestrad terutama di puskesmas, dengan Nakestrad profesional yang memapu memberikan pelayanan kesehatan yang aman dan bekualitas pada lansia. Masih banyak lansia yang memanfaatkan ramuan buatan sendiri, oleh karena itu perlunya peningkatan program asuhan mandiri dan keterampilan dan pemberdayaan lansia untuk peningkatan kesehatan keluarga.

\section{UCAPAN TERIMA KASIH}

Terima kasih kami ucapkan kepada Kepala Puslitbang Humaniora dan Manajemen Kesehatan, atas dukungannya untuk terlaksananya analisis ini. Terima kasih kepada Tim Manajemen Data Badan Litbangkes Kemenkes RI dan Tim Mandat UPF Inovasi Teknologi Kesehatan, atas penyediaan data Riskesdas 2018.

\section{KONTRIBUSI PENULIS}

Rukmini adalah kontributor utama yang membuat konsep artikel, analisis data dan menulis artikel secara keseluruhan. Lusi Kristiani adalah kontributor anggota yang membantu memperbaiki artikel dan membuat tabel dan grafik.

\section{DAFTAR PUSTAKA}

Andriyanti and Wahjudi, R. M. (2016) 'Tingkat penerimaan penggunaan jamu sebagai alternatif penggunaan obat modern pada masyarakat ekonomi rendah-menengah dan atas', Masyarakat, 
Kebudayaan dan Politik, 29(3), pp. 133-145. doi: 10.20473/mkp.V29I32016.133-145.

Aprilla, G. G.(2020) 'Gambaran Karateristik Pemanfaatan Pelayanan Kesehatan Tradisional', Jurnal IImiah Kesehatan, 12(1 Maret), pp. 101-122. doi: 10.37012/jik.v12i1.183.

Ariastuti, R. and Herawati, V. D. (2019) 'Asuhan Mandiri Tanaman Obat Keluarga (TOGA) dalam Upaya Peningkatan Kesehatan Masyarakat Kecamatan Banyudono, Boyolali', Journal of Pharmaceutical and Medicinal Sciences, 4(2), pp. 5-12.

Balitbangkes Kemenkes RI (2019) Laporan Nasional Riskesdas 2018. Lembaga Penerbit Badan Penelitian dan Pengembangan Kesehatan. Jakarta.

BPS RI (2020) 'Umur Harapan Hidup (UHH) Saat Lahir Menurut Provinsi (Metode Baru) 2010 - 2019'. Jakarta: Badan Pusat Statistik, p. 93. Available at: https://www.bps.go.id/dynamictable/2018/04/16/1298/ angka-harapan-hidup-saat-lahir-menurut-provinsi2010-2017.html.

Fatonah, S. and Hernawilly (2012) 'Perilaku Pemilihan Obat Tradisional Untuk Menurunkan Tekanan Darah Pada Lansia Di kota Bandar Lampung', Jurnal Keperawatan, VIII(1), pp. 1-9.

Handayani, R. P., Puspariki, J. and Nurmala, T. (2019) 'Persepsi masyarakat kabupaten purwakarta terhadap pengobatan tradisional berdasarkan kelompok usia', Pharma Explore: Jurnal IImiah Farmasi, 4(2), pp. 1-12.

Imandiri1, A. and Septriana, M. (2019) 'Sosialisasi Asuhan Mandiri Toga Dan Akupresur Di Puskesmas Gading Surabaya', 01(1), pp. 8-10. doi: 10.20473/ dc.v1i1.2019.8-10.

Jennifer, H. and Saptutyningsih, E. (2015) 'Preferensi Individu Terhadap Pengobatan Tradisional di Indonesia', Jurnal Ekonomi dan Studi Pembangunan, 16(1 April), pp. 26-41. Available at: https://journal. umy.ac.id/index.php/esp/article/view/1214.

Kartikasari Ellia, B. D. A. (2018) 'Pengaruh Formulasi Sediaan Herbal Param Kocok Dari Kencur, Kunir Putih Dan Daun Pacar Air Terhadap Skala Nyeri Sendi Pada Lansia', Journal Nursing Care and Biomolecular, 3(Vol 3, No 2 (2018)), pp. 84-87. doi: http://dx.doi.org/10.32700/jnc.v3i2.89.

Kementerian Kesehatan RI (2015) 'Keputusan Menteri Kesehatan Republik Indonesia Nomor HK.02.02/MENKES/52/2015 tentang Rencana Strategis Kementerian Kesehatan Tahun 2015 2019', Kementerian Kesehatan RI, pp. 1-128. Available at: https://www.depkes.go.id/article/ view/19020100003/hari-kanker-sedunia-2019.html.

Kementerian Kesehatan RI (2016) 'Peraturan Menteri Kesehatan Republik Indonesia No. 25 Tahun 2016 tentang Rencana Aksi Nasional Kesehatan Lanjut Usia Tahun 2016 -2019'. Jakarta, pp. 1-97.

Kusuma, T. M. et al. (2020) 'Hubungan Tingkat Pengetahuan dan Sikap terhadap Kebiasaan Konsumsi Jamu pada Mayarakat Magelang Tahun 2019', Pharmacon: Jurnal Farmasi Indonesia, (Edisi Khusus (seminar IAI Jateng)), pp. 37-42. doi:

\subsection{7/pharmacon.v0i0.10857.}

Liana, Y. (2017) 'Analisis faktor-faktor yang mempengaruhi keluarga dalam penggunaan obat tradisional sebagai swamedikasi di Desa Tuguharum Kecamatan Madang Raya', Jurnal Kedokteran dan Kesehatan, 4(3), pp. 121-128.

Marwati, M. and Amidi, A. (2019) 'Pengaruh Budaya, Persepsi, Dan Kepercayaan Terhadap Keputusan Pembelian Obat Herbal', Jurnal IImu Manajemen, 7(2), p. 168. doi: 10.32502/jimn.v7i2.1567.

Nandatia, R. P., Xaverius, F. And Sadewo, S. (2019) 'Praktik Mencari Kesembuhan Bagi Lanjut Usia Surabaya', Jurnal Paradigma, 7(3), pp. 1-4. Available at: https://jurnalmahasiswa.unesa.ac.id/index.php/ paradigma/article/view/29329.

Prasetyani, D. and Andika, R. (2019) 'Peningkatan Pengetahuan te ntang Manajemen Hipertensi dan Pemanfaatan Tanaman Obat Keluarga pada Penderita Hipertensi di Desa Menganti Cilacap', Jurnal Pengabdian Masyarakat Al Irsyad, 1(1), pp. 1-7. Available at: http://jpma.stikesalirsyadclp.ac.id/ index.php/alirsyad/article/view/26/13.

Putri Lailil; Adinugroho, Sigit, G. F. M. (2018) 'Pemilihan Alternatif Simplisia Nabati Untuk Indikasi Gangguan Kesehatan Menggunakan Metode Analytical Network Process (ANP) dan Simple Additive Weighting (SAW)', Jurnal Pengembangan Teknologi Informasi dan Ilmu Komputer, 2(Vol 2 No 11 (2018)), pp. 5229-5234. Available at: http://j-ptiik.ub.ac.id/ index.php/j-ptiik/article/view/3240.

Republik Indonesia (1998) 'Undang-Undang Republik Indonesia No. 13 Tahun 1998 tentang Kesejahteraan Lanjut Usia'. Jakarta, pp. 1-24.

Republik Indonesia (2009) 'Undang-Undang RI No. 36 Tahun 2009 tentang Kesehatan', 2, pp. 1-77.

Republik Indonesia (2014) 'Peraturan Pemerintah nomor 103 Tahun 2014 tentang Pelayanan Kesehatan Tradisional. Sekretariat Negara. Jakarta', pp. 1-39.

Rukmini et al. (2019) 'Kajian Pelayanan Kesehatan Tradisional Integrasi di UPF Inovasi Teknologi Kesehatan. Laporan penelitian UPF Inovasi Teknologi Kesehatan, Puslitbang Humaniora dan Manajemen Kesehatan. Surabaya'.

Rukmini and Oktarina (2020) 'Inovasi Program Pelayanan Kesehatan Tradisional Pada Lansia Di Puskesmas Made Kota Surabaya Innovation of Traditional Health Services Programs for Elderly', Buletin Penelitian Sistem Kesehatan, 23(2 April), pp. 135-144. doi: https://doi.org/10.22435/hsr.v23i2. 3101.

Stefani, H. et al. (2020) 'Penyuluhan Penggunaan Obat Tradisional Kepada Lansia Puskesmas Palanro Kabupaten Barru', Jurnal Pengabdian Kefarmasian, 1(1), pp. 23-26. doi: https://doi.org/10.32382/jpk.v1i1. 1487.

Sugarna, A., Marini and Nurhayatina, R. (2019) 'Tingkat Pengetahuan Penggunaan Jamu Sebagai Upaya Swamedikasi Di RT 01 RW 01 Desa Japara', Jurnal Farmasi Muhammadiyah Kuningan, 4(2), pp. 18-23. Available at: http://ojs.stikes-muhammadiyahku.ac.id/ index.php/jurnalfarmaku/article/view/78/35.

Suharmiati, S., Handayani, L. and N, Z. H. (2020) 
'Pemanfaatan Pelayanan Kesehatan Tradisional Integrasi di Rumah Sakit Pemerintah. Studi di 5 Provinsi Indonesia', Buletin Penelitian Sistem Kesehatan, 23(3 April), pp. 126-134. doi: https://doi.org/10.22435/hsr.v23i2.2361.

Suiroaka, I. P. (2012) Penyakit Degeneratif : Mencegah Mengenal dan Mengurangi 9 Faktor Risiko 9 Penyakit Degeratif. Jojakarta: Nuh Medika. Available at: http://repository.poltekkes-denpasar.ac.id/3290/1/9 - buku penyakit degeneratif.pdf.

Supardi, S., Herman, M. and Yuniar, Y. (2011) 'Penggunaan Jamu Buatan Sendiri Di Indonesia (Analisis Data Riset Kesehatan Dasar Tahun 2010)', Buletin Penelitian Sistem Kesehatan, 14(4 Okt), pp. 375-381. doi: 10.22435/bpsk.v14i4Okt.1382.

Supardi, S. and Notosiswoyo, M. (2005) 'Pengobatan sendiri Sakit Kepala, Demam, Batuk dan Pilek pada Masyarakat di desa Ciwalen Kecamatan Warungkondang Kabupaten Cianjur Jawa Barat', Majallah IImu Kefarmasian, II(3), pp. 134-144. doi: 10.7454/psr.v2i3.3390.

Supardi, S. and Susyanti, A. L. (2010) 'Penggunaan Obat Tradisional Dalam Upaya Pengobatan Sendiri DI Indonesia (Analisis Data Susenas Tahun 2007)', Buleitin Penelitian Sistem Kesehatan, 38(2), pp. 80-89.

Vera, Y. and Yanti, S. (2020) 'Penyuluhan Pemanfaatan Tanaman Obat dan Obat Tradisional Indonesia untuk Pencegahan dan Penanggulangan Penyakit Hipertensi di Desa Salam Bue', Jurnal Education and development, 8(1), pp. 11-14. 